(昭和 35 年 1 月 25 日受理)

ナイロン 6 繊維の乾熱和よび蒸熱処理による染色性の変化につルて 武竬川女子大学 安田武

\title{
ON VARIATION OF DYEING PROPERTY BY DRY HEAT SETTING AND WET HEAT SETTING OF NYLON 6 FIBER
}

\section{By Takeshi Yasuda}

(Mukogawa Women's University, Ikebiraki, Nishinomiya City, Hyogo Prefecture, Japan)

There are two methods of heat setting of nylon fabrics, i.e. dry heat setting and wet heat setting (steam setting). As a result of comparative examination, in respect of dyeing property, of the materials treated by those two methods, it was proved that diffusion velosity is higher, and absorbed quantity is larger in the materials treated by wet heat setting than in those processed by dry heat setting, even if those materials are equal in density. It was presumed that in the method of wet heat setting. due to the presence of water molecule, locomotion of molecule segment in amorphous region is easy, the growth of crystallit is conspicuous, the gaps between crystallits become large, and that in the method of dry heat setting crystallit increases in number rather than in volume, crystallits that are smaller than those in the method of wet heat setting are scattered in places, and gaps between crystallits become smaller. (Received January 25, 1960)

\section{1. 緒言}

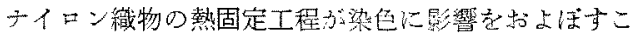
とは，與昧劣る問題で㤐る。熱処理によつて結晶性の変

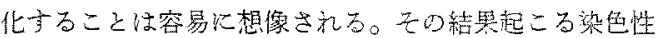

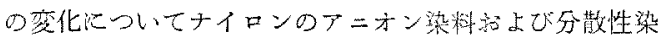
料の染色に执いて，結晶化度の大当い程むたタリスタり ットの配列度の大きい程，染色速度㤬幄くなるが，平衡 染着量はこれら微細精造の影䇾を受けないという考え

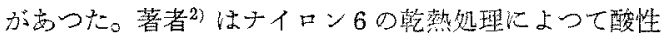
怘よび分散性染料の染色性が变化するの法, 結晶領垃の 拉大が起こり, その結果, 非結晶領域に露出していた染 着活性のアミノ本端基やアミド基が結晶領域に包理され ると共に非結晶嘶域の分子間孔除か小さくなり，染料の

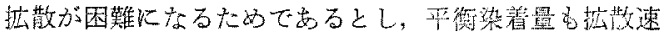
度も其に減少することを明らふ炕した。艺の後この考

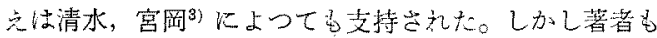
その緒言で述ぺたら 性区別しなければならない。すなが，乾熱処理と蒸熱

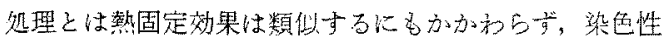

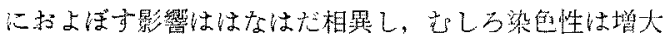

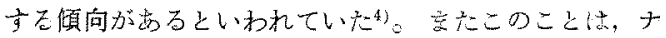
イロンの然止め, ウーリ一加工に蒸熱が用いられ，ての 結果起こる染色性の变化が，峨物の乾熱固定による染色 性の変化と必ずしも一致しないとい5ことから, 㝜際家
によつて早くから哚い関心が払われていた。この闍題に

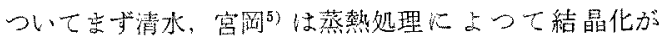
起こるが，同時に配向性の低下を伴らために染料拡散速

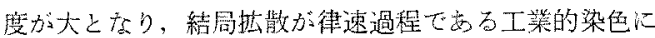

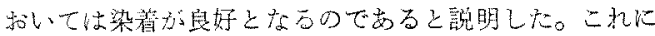

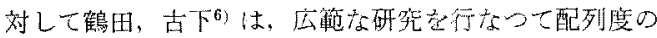
低下による是のでないということ強く主㖘し，蒸熱の

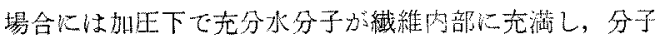

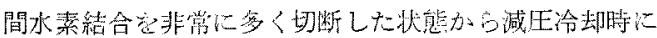

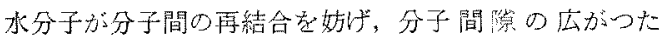

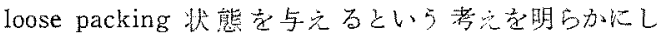

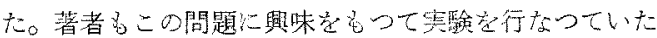
ので上記の諸説に敬発されるとこるはなはた多からたが、

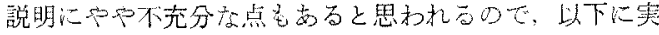

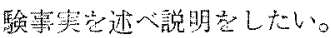

\section{2. 試料}

ナイロン 6 瀻維 (アミラン, $210 \mathrm{~d} / 15,3 / 4 \mathrm{~S}$, タイフ

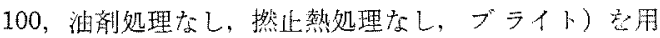
い，乾熱処理の場台には原系をスコア、ールサ400，2 $\mathrm{g} / l+$ 第二燐酸ソーダ， $2 \mathrm{~g} / l$ で $40^{\circ} \mathrm{C}, 30$ 分洗い，蒸留水で 洗つて風乾し，金虽製の枠潦いて電気乾燥器を用いて

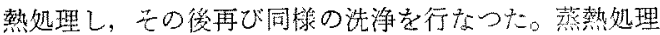
の場合以は原芽を金殿製の枠に巻いてオートクレーブ中 に欲り，約 10 分で宜温し，所定の温度て 10 分間処理し 
た後，ブローして約 5 分て取り出し，天の後上記の如总

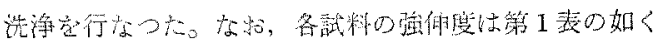
て大苏つ大。

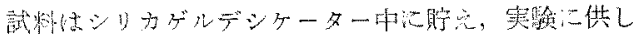
た。

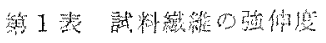

\begin{tabular}{|c|c|c|c|c|}
\hline & & 強答 & giden & 㜊 $\%$ \\
\hline \multicolumn{2}{|c|}{ blank } & & 5.5 & 10.1 \\
\hline 乾 & $198 \mathrm{C}$ & & 5.8 & 12.2 \\
\hline 嚢 & $178 \mathrm{C}$ & & 5.6 & 9.2 \\
\hline 雏 & $110 \mathrm{C}$ & & 5.8 & 10.3 \\
\hline 䓵 & $120 \mathrm{C}$ & & 5.7 & 9.6 \\
\hline
\end{tabular}

\section{こ. 突歌方法および結果}

\section{（1）嫱留收縮の变化}

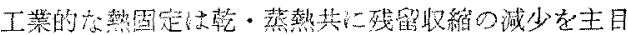

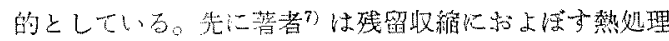
の效果老調心，特に適度の水分の存在が効果的でるこ

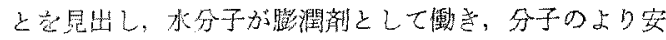

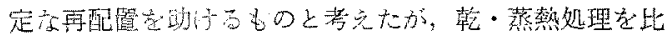

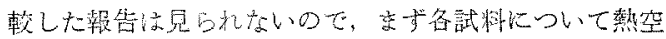

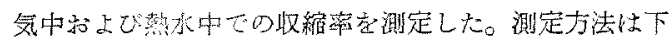
記の力法によつた。

(A) 采变約 $15 \mathrm{~cm}$ とり，10 cm の間隔にマークをつ

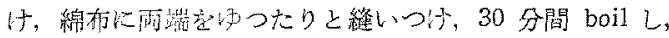

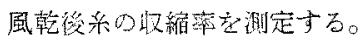

（B） A と同様のマークした系に $0.11 \mathrm{~g} / 210 \mathrm{~d}$ の荷重を が外，ビーカー中で boil L，風乾後收維率老測定する。 （C）A上同椂のマークした系に，B上同じ荷重起か

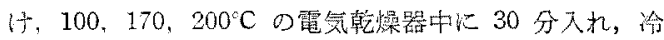

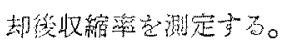

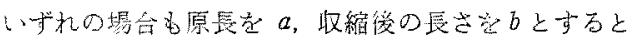

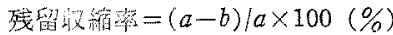

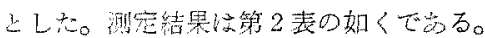

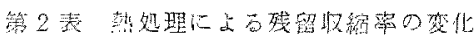

\begin{tabular}{|c|c|c|c|c|c|c|}
\hline \multirow{2}{*}{ 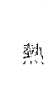 } & \multirow{2}{*}{ 浬 歾 } & \multirow{2}{*}{$A$ 戟 } & \multirow{2}{*}{ B济 } & \multicolumn{2}{|c|}{ C } & 法 \\
\hline & & & & $100^{\circ} \mathrm{C}$ & $170^{\circ} \mathrm{C}$ & $200^{\circ} \mathrm{C}$ \\
\hline 擪 & th & 6.7 & 6.5 & 0.1 & 5.6 & 12.7 \\
\hline 䙪 & $138^{\circ} \mathrm{C}$ & 5.0 & 6.1 & -0.7 & 5.7 & 13.9 \\
\hline 琝 & $178^{\circ} \mathrm{C}$ & 0.0 & 3.9 & -0.3 & 3.7 & 12.2 \\
\hline 蒸 & $110^{\circ} \mathrm{C}$ & 0.0 & 0.8 & -0.6 & 4.0 & 13.3 \\
\hline 烝 & $120^{\circ} \mathrm{C}$ & 0.0 & 0.0 & -0.4 & 3.6 & 7. 6 \\
\hline
\end{tabular}

この結塐を見る上蒸熱处理の場合汇は乾熱处理に比し て低い温度配大きい効果示している。

\section{（2）密度の恋化}

谷試料について，木下多の方法に準じて密度を測定し た。すな放台，系学約 $3 \mathrm{~mm}$ に切断し，五酸化燐デシ

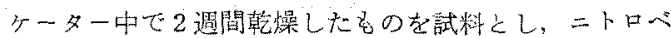

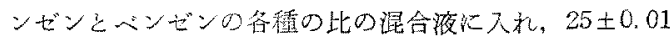

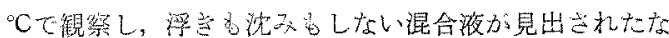
ら媇これをオストワルド（木下改良）型の比重㖕儿移

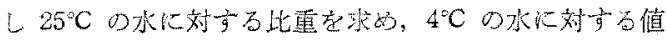

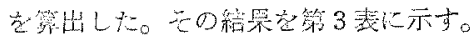

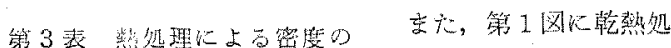

\begin{tabular}{|c|c|c|c|c|}
\hline \multicolumn{4}{|c|}{ 峦化 } & \multirow{2}{*}{ 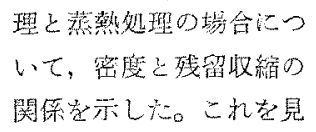 } \\
\hline 䓡 & 処 理 & & 签 & \\
\hline 原 & 係 & & 1411 & \\
\hline 赎 & $138^{\circ} \mathrm{C}$ & & 1418 & 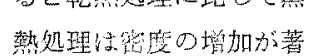 \\
\hline 乾 & $178^{\circ} \mathrm{C}$ & & 1469 & , \\
\hline 蘩 & $110^{\circ} \mathrm{C}$ & & 1432 & . \\
\hline 䓙 & $120^{\circ} \mathrm{C}$ & & 1490 & 少が渚し \\
\hline
\end{tabular}

グタか子。

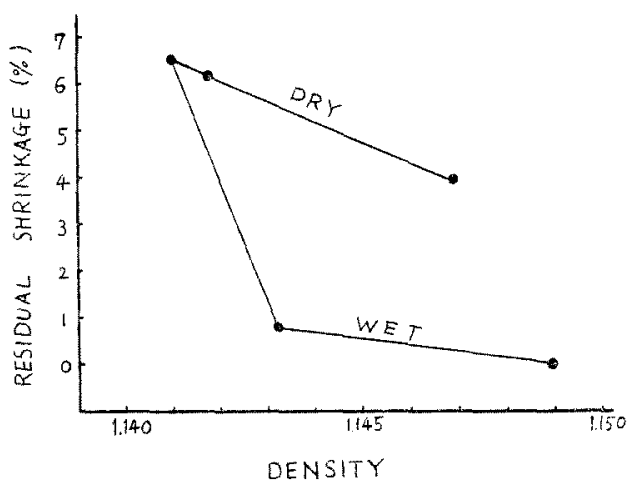

Fig.1. Density-residual shrinkage. (by dry heat set and wet heat set)

\section{（3）染色実験の方法}

Acit Orange II, Celliton Fast Blue B, Azine Brilliant Blue 6B，主用いた。酸性拈上び直揬染料は酢酸》 一ダを用いて境新し，分敬监然料はアルニールを用いて

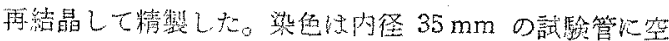
灾冷却管をつけたゴム模をし，ての中心を通してステン レス線觉さしスれ，その先にステンレス線製のパスケッ

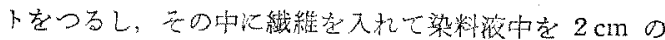
振幅で每分約 75 回の周期で上下に機械的に振動させた。 加温飞は $\pm 0.1^{\circ} \mathrm{C}$ に保つた恒温水瞥を用いた。

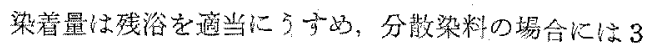

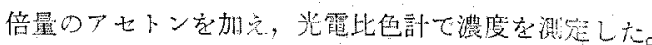


な Celliton Fast Blue B の精整品は分频性が悪いの て工策品にアルコールで再結晶して精製したエマールサ

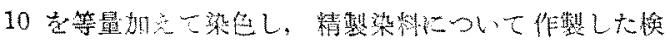

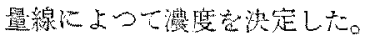

こ和ら染粗心構造克第 2 図に示才。

筷 2 成 染料の精造武

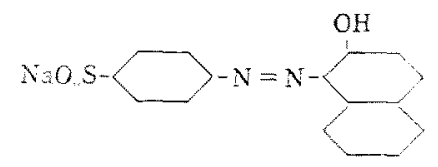

Acid Orange II.

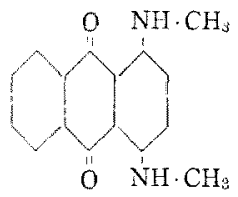

Celliton Fast Blue B.
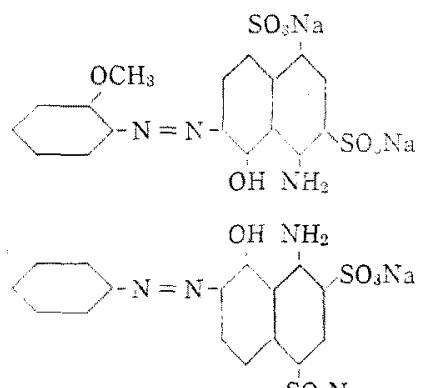

$\mathrm{SO}_{2} \mathrm{Na}$

Azine Brilliant Blue $6 \mathrm{~B}$.

\section{（4）平重染着量の変化}

(A) Orange II $2.5,4.0,6.0,7.5,10.0,12.5$ 各 $\mathrm{mg} / 25 \mathrm{cc} / 0.5 \mathrm{~g}$ 䋊維の条件で $80^{\circ} \mathrm{C}, 5$ 時間の染色老行な

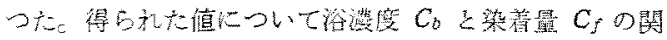

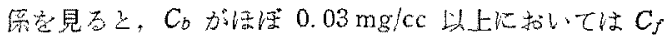
は鉋和達しているので先の籍四の $C_{f}$ の平均值をとつ to

(B) Celliton Fast Blue B 5.0, 10.0, 15.0, 20.0, $25.0,30.0 \mathrm{mg} / 25 \mathrm{cc} / 0.5 \mathrm{~g}$ 絾維 0 多件を $80 \mathrm{C}, 10$ 時間

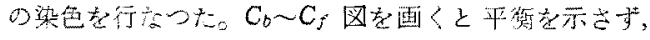

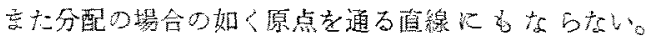
Glenz 上Beckman"がアタリ心瀻料の染色について行 なつた害験の場合の如く，分配之 Langmuir 型の吸着

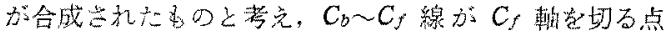
の值を近似的心䳜和檤とした。

(C) Azine Brilliant Blue $6 \mathrm{~B} 7.0 \mathrm{mg} / 25 \mathrm{cc} / 0.5 \mathrm{~g}$ 䋐 維の条件た $90^{\circ} \mathrm{C}, 9$ 時間の染色を行なつて平衡值を求 尚六。
これらの䋨然第4 琵示方。

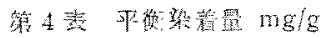

\begin{tabular}{|c|c|c|c|c|}
\hline 熱処伍 & 理 & Orange Il & $\begin{array}{c}\text { Celliton Fa } \\
\text { Blue B }\end{array}$ & $\begin{array}{l}\text { Dine Brilliant } \\
\text { Blue } 6 \mathrm{~B}\end{array}$ \\
\hline 原 & 䔉 & 10.73 & 2.68 & 8.72 \\
\hline 䩪 & $138^{\circ} \mathrm{C}$ & 10.40 & 2.56 & 8.26 \\
\hline 施 & $178^{\circ} \mathrm{C}$ & 10.26 & 1.96 & 6.18 \\
\hline 蒸 & $110^{\circ} \mathrm{C}$ & 10.67 & 2.52 & 8. 44 \\
\hline 䓠 & $120^{\circ} \mathrm{C}$ & 10.50 & 2. 33 & 8.20 \\
\hline
\end{tabular}

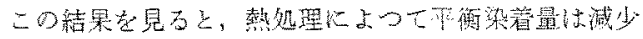

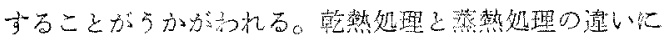

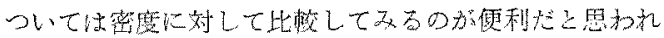

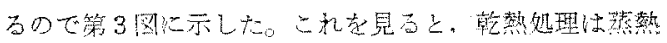

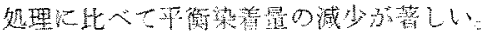

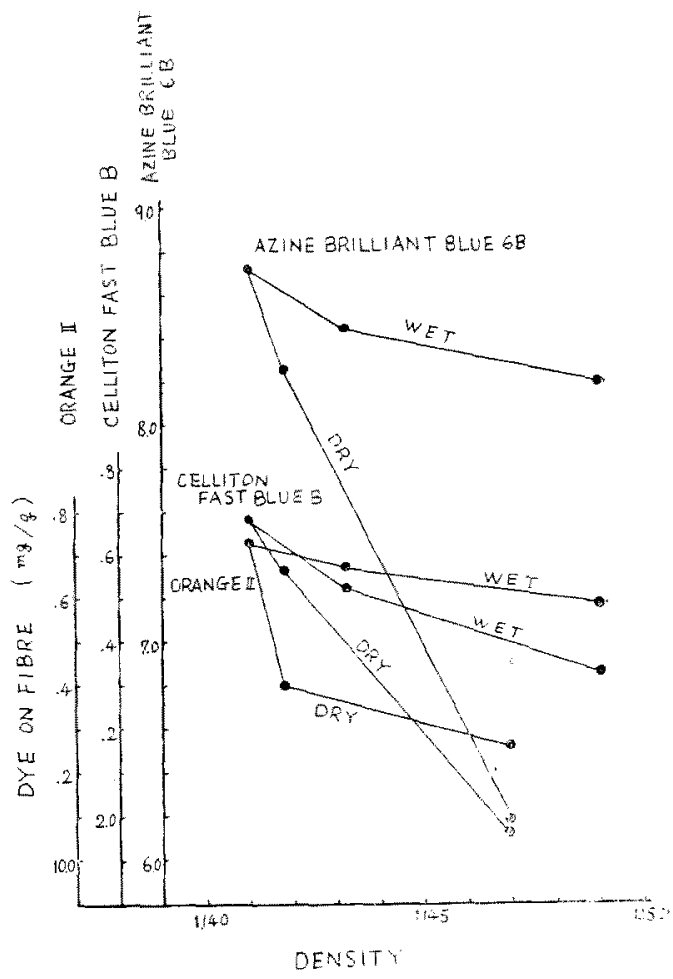

Fig. 3. Density-due absorption.

\section{（5）拡散係数の変化}

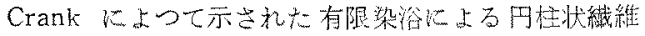

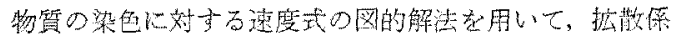

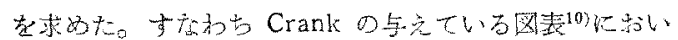

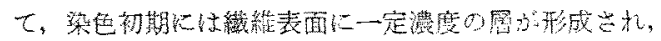

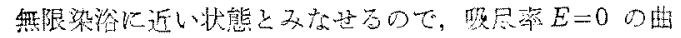

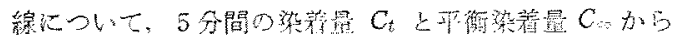


圪散係数 $D$ 卆計算した。瀻維の半径 $r$ はデニールの実 測值上り求的， $r^{2}=434.5 \times 10^{-8}$ とした。染色条件は, Orange II $20 \mathrm{mg} / 50 \mathrm{cc} / \mathrm{g}$ (水酢 $0.02 \mathrm{cc} / 100 \mathrm{cc}$ ) $80^{\circ} \mathrm{C}$ $C_{\infty}=5 \mathrm{hr}$, Celliton Fast Blue B $20 \mathrm{mg} / 50 \mathrm{cc} / \mathrm{g} 80^{\circ} \mathrm{C} \mathrm{C} C_{\infty}$ $=10 \mathrm{hr}$, Azine Brilliant Blue $6 \mathrm{~B} 4 \mathrm{mg} / 50 \mathrm{cc} / 0.5 \mathrm{~g}$ (冰 酶 $0.005 \mathrm{cc} / 100 \mathrm{cc}) 90^{\circ} \mathrm{C} C_{\infty}=9 \mathrm{hr}$ を用いた。その結果 起第 5 裁に示或。

この結果を密蚁心対して図示すると第4 図の如くな

第 5 表 抬散保数 $\mathrm{cm}^{2} / \mathrm{min}$

\begin{tabular}{|c|c|c|c|c|}
\hline \multicolumn{2}{|c|}{ 染処琹 染料 } & Orange II & $\begin{array}{c}\text { Celliton Fast } \\
\text { Blue } B\end{array}$ & $\begin{array}{c}\text { Azine Brilliant } \\
\text { Blue } 6 \mathrm{~B}\end{array}$ \\
\hline 原 & 采 & $7.01 \times 10^{-8}$ & $3.37 \times 10^{-8}$ & $0.60 \times 10^{-8}$ \\
\hline 献 & $138^{\circ} \mathrm{C}$ & 5.61 & 3.20 & 0.06 \\
\hline 乾 & $178^{\circ} \mathrm{C}$ & 2. 17 & 2.57 & 0.16 \\
\hline 㸃 & $110^{\circ} \mathrm{C}$ & 5.34 & 2.45 & 0.67 \\
\hline 戚 & $120^{\circ} \mathrm{C}$ & 5.34 & 3.04 & 0.82 \\
\hline
\end{tabular}

る。乾熱观理によつて拡散係数は著しく小さくなるが，

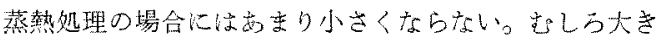
くなる場合吕吉る。

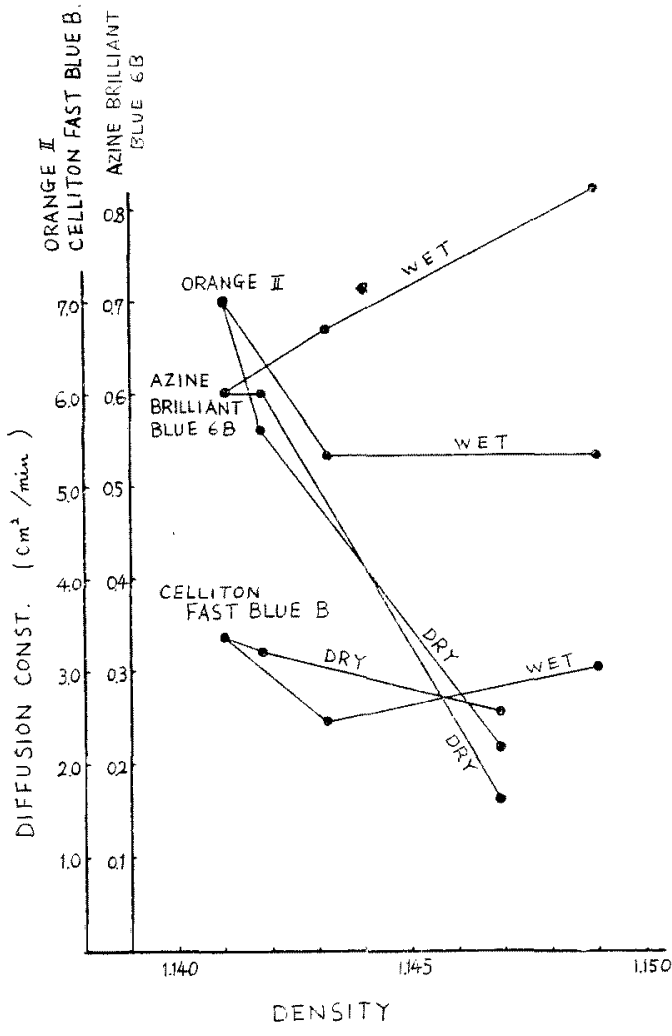

Fig. 4. Density-due diffusion velosity.

\section{4. 実験結果の考察}

第3 表に明らかなように，同じ温度で比較すると乾熱 观理より葓熱処理の方が密度の增加が著しい。これは水 が存在した厅が膨潤作用によつてセグメントの移動が容 易でクリスタリットの生長拡大が起こりゃ方いのである と䍐われる。むた残留取樎の減少も著しいがこれれ水 の存在によつて一層容易にヒグメントが不安定位置の水 素結合老脱して安定位圆に移動し, 再び水素結合を生成 して安定化するのて荡る5と考光られる。

とこるて同じ密度について比較してみても, 乾熱処理 と畓熱処理で残留收綰や染色性は著しい差が女る。これ は明らが耐方法によつて起こる微絸棈浩变化に相異の 幽ることを示しているものと考えねはならない。以下に この相異について考察を進めよ5。

すなわら実驗事実によれば同じ密度で。

(1) 残留取䈹は蒸熱処理の方が小さい。（第 1 図参 照）これは同じ密度でも蒸熱処理の方が不安定位置にあ るセグメントが少く，結晶領域のま上きりがよいのに対

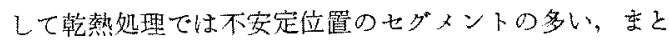

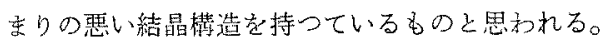

（2）同し密度で名平衡染着量恃蒸熟処理の方が大き い(第3図参照)これは蒸熱处理の方が染料の侵入し 得る領域に露出している染着㢁塺が多いこ之圭示してい ミ。しかし密度が等しいので如るから非粕晶領域が多い といらことてはなくて，非結晶領域のポアサイズ分布 が蕉熱処理では大きい万に偏在していると考放ばなら 地い。更に架料の侵入し得方領域性染料分子の大きさに 上つて相異すると教光られるか，分子の小さい時に悢 乾熱処理でもかなり内部まで侵入し得るので基熱処理と の差は赫り著しくないが，分子が大きいと畭熱処理が 染料分子の侵入が著しく困難となるので等熱処理との差 は大きくなると思われる。染粫の種類が是るので染着機 棈が同じでないから，敞密な比較はできないが，分子の

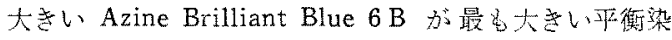
箱量の差を示しているのは與味が充る。

(3) 同じ密度で㧓散係数は蒸熱処理の万が大 い。(第 4 图参照)これは非結晶領域のポアサイズが大 きいことを示していると孝えられる。Azine Brilliant Blue 6B の場合との差が最も著しく，蒸熱処理に上り 原系よりむ大きくなつていることから，染料分子の大き さとポアサイズとの関軏が考克られる。一なわち小さい 染料では孔谅の大きさがあまり問題にならずしてるその 数が問題になるが，大老い染料では孔隚の大きさが摭散 を支配すると考光られる。ポアサイズは原系より筣熱処 理の方が大きとすると，比較的大きい染料分子は原系

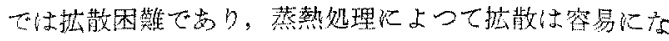


る傾向を示す。しかし，比較的小さい染料分子ではとの

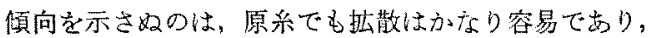

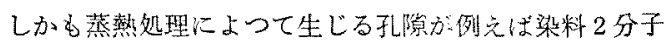
以上が並列して通過し得る位に巨大なものでない限り， 之の数の影響艺受けるが非結昆領域全体は量的に变化が ないとすると結局孔陌の数は减少していることになり， その影響受けて抬散保数は若干低下するのであるうと 思放れる。蒸熱処理の場合 Azine Brilliant Blue 6 B の 抬散保数は原糸上り大きいのに平衡染着量が原系上り低 いの。侵入可能の空洞の数が少いとい5よ5に考皇れぱ 一応らなずける。

以上の考察から次の上5视細梅造变化が考兄られ る。すなわ方，分子鎖員の渾動は結晶領域中上り毛非結 晶領域でのが一層自由であるから，本実験の上うな熱 処理によつて既存の結晶部分の分散は克主り起こらない ものとし非結晶領域に存在する分于鎖員の移動が主とし て起こるとする。乾熱処理と蒸熱処理の最も大きい相翼

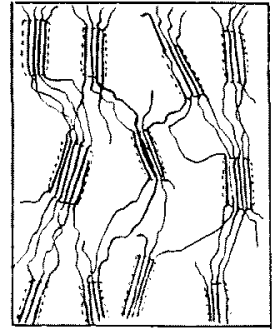

BLANK

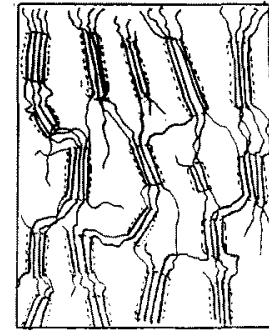

DRY SETTING
Fig. 5. Representation of structures in the fibre.

众繝

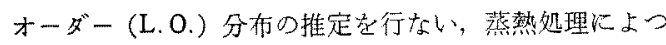
て L.O. の中間の領域が消失し, 高結晶領域と非晶領域 との境界が比较的画然とするという極めて興棟古る結果

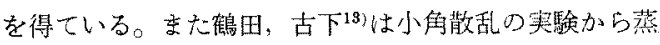
熱処理によつて著しく結唱化度找よびクリタリットが 大きくなることを諗就ているこれらの結果は染色性の 変化から推論したとこると大体一致する。

\section{5. 結}

論

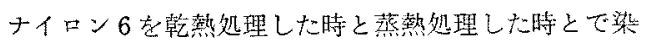
色性の变化は同じでない。一般に蒸熱処理の方が染料の 拉散係数と平衡染着量は大きく，残留収縮は小さい。 れらのことから筣熱処理では水分子の存在によつて非結 晶領域の分子セグメントの移動が容易で結晶の成長が著 しく，結晶間隐が大さい構造となるのに対して，乾熱処 理の場合には結晶の成長は比較的少々，蒸熱赺理の場合

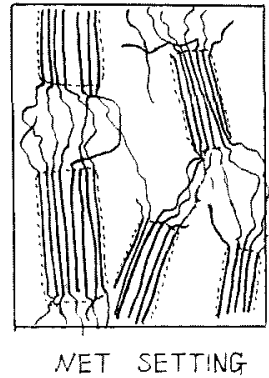

より小い結晶が各所 に散在し結晶間隚が小 さい構造となつている ものと考完られる。 本研究比つい者盛 な御助言を賜つた東工 大前田弘邦教授並びに 福井大清水融助教授, 日本レイヨン古下昭蜼 氏括よび本研究に用い たナイロン試料を御恵 与下さいました東洋レーヨン中央研究所吉田皆蔵氏に対 し心から御礼を申上交。

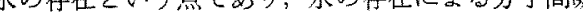
内部エネルギーの低下によつて非結晶領域の分子鎖貝は より容易に滑動し得ると考えると，見かけ上等しい密度 のものでる乾熱処理に上万場合には比渂的局所的なクリ

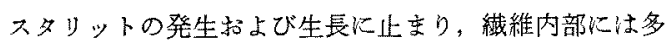
数の小規模な結晶領域が散在し（微晶構造）非結晶領域 のセグタントはかなりもつれた構造となるのに対して，

蒸熱処理の場合には比較的大規模なクリスタリットが塊 状に配置され（巨晶構造）非結晶領域の不安定な位琶の セグメントはかなり大きく移重して安定位置に招らつい た搆造となるでるらと思われる。実際に染色の行なわ れる非結晶領域のみに着目すれば微晶的变化の場合には 非結晶領域が少なくなり孔隚の大きさも小さく数も少く なるのに対して，巨晶的変化の場合には非結晶領域の数 は少くなるが，分子鎖員の一個の非結晶領域の大きさは

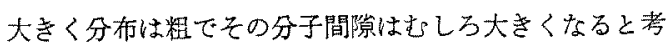
党られるのである。第5图はこの考觉を模型的に示した ものである。

\section{文献}

1) Munden, Palmer ; J. Soc. Dyers \& Col., 63, 430 (1947)

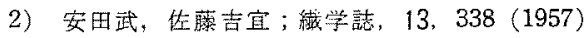

3)清水融, 宮岡宇一郎; 䋐学誌, 14, 563 (1958)

4) Lyle, Jannarone \& Thomas ; Ame. Dyes. Rept. , 40. 585 (1951)

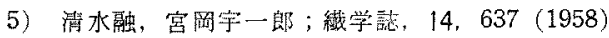

6）鶴田基弘，古下昭堆；高分化，16，274（1957）

7) 安田武；絿学誌，10，186(1954)

8）木下幸夫；洋 $レ, 9 ， 1$ (1954)

9) O.Glenz, W. Beckmann; Mell. Textilber., 38 , 296 (1957)

10) J.Crank; The Mathematics of Diffusion, p.71 (1956)

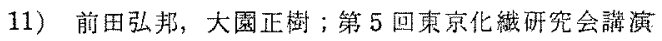
集 p. 14 (1959)

12)金綱久明，織学点；14，442（1958）

13）鶴田基弘，古下昭雄；高分化，16，391（1959） 